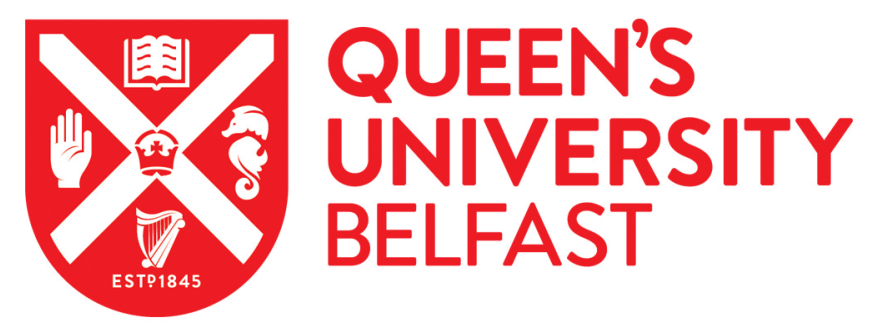

\title{
Managing contested spaces: Public managers, obscured mechanisms and the legacy of the past in Northern Ireland
}

Murphy, J., McDowell, S., Braniff, M., \& Denyer, D. (2017). Managing contested spaces: Public managers, obscured mechanisms and the legacy of the past in Northern Ireland. Environment and Planning C: Government and Policy. https://doi.org/10.1177/2399654417714800

Published in:

Environment and Planning C: Government and Policy

Document Version:

Peer reviewed version

Queen's University Belfast - Research Portal:

Link to publication record in Queen's University Belfast Research Portal

Publisher rights

Copyright 2017 the authors.

This work is made available online in accordance with the publisher's policies. Please refer to any applicable terms of use of the publisher.

\section{General rights}

Copyright for the publications made accessible via the Queen's University Belfast Research Portal is retained by the author(s) and / or other copyright owners and it is a condition of accessing these publications that users recognise and abide by the legal requirements associated with these rights.

Take down policy

The Research Portal is Queen's institutional repository that provides access to Queen's research output. Every effort has been made to ensure that content in the Research Portal does not infringe any person's rights, or applicable UK laws. If you discover content in the Research Portal that you believe breaches copyright or violates any law, please contact openaccess@qub.ac.uk. 


\section{Environment and Planning C: Politics and Space}

\section{Managing contested spaces: public managers, obscured mechanisms and the legacy of the past in Northern Ireland}

\begin{tabular}{|r|l|}
\hline Journal: & Environment and Planning C: Politics and Space \\
\hline Manuscript ID & EPC-16/119.R1 \\
\hline Manuscript Type: & Article \\
\hline Keywords: & $\begin{array}{l}\text { Conflict transformation, urban management, } \\
\text { mechanisms, Northern Ireland }\end{array}$ \\
\hline Abstract: & $\begin{array}{l}\text { Societies emerging from ethno-political and inter-communal conflict face a } \\
\text { range of complex problems that stem directly from the recent lived } \\
\text { experience of bloodshed and injury, militarisation, securitisation and } \\
\text { segregation. As institutional agents in such an environment, public } \\
\text { managers perform the dual role of both interpreting public policy and } \\
\text { implementing it within a politically contested space and place. In this } \\
\text { article we address how managers cope with the outworking of ethno- } \\
\text { nationalist conflict and peace building within government processes and } \\
\text { policy implementation and contend this is a subject of emerging concern } \\
\text { within the wider public administration, urban studies and conflict } \\
\text { literature. Using data from a witness seminar initiative on the Northern } \\
\text { Ireland conflict transformation experience, we explain how public sector } \\
\text { managers make sense of their role in post-agreement public management } \\
\text { and highlight the importance of three identified mechanisms; 'bricolage', } \\
\text { 'diffusion' and 'translation' in the management of public sector } \\
\text { organisations and urban spaces in a context of entrenched conflict and an } \\
\text { uncertain path to peace. }\end{array}$ \\
\hline
\end{tabular}

\section{SCHOLARONE $^{\text {"x }}$}

Manuscripts 
Managing contested spaces: public managers, obscured mechanisms and the legacy of the past in Northern Ireland

Revision

\begin{abstract}
Societies emerging from ethno-political and inter-communal conflict face a range of complex problems that stem directly from the recent lived experience of bloodshed and injury, militarisation, securitisation and segregation. As institutional agents in such an environment, public managers perform the dual role of both interpreting public policy and implementing it within a politically contested space and place. In this article we address how managers cope with the outworking of ethno-nationalist conflict and peace building within government processes and policy implementation and contend this is a subject of emerging concern within the wider public administration, urban studies and conflict literature. Using data from a witness seminar initiative on the Northern Ireland conflict transformation experience, we explain how public sector managers make sense of their role in post-agreement public management and highlight the importance of three identified mechanisms; 'bricolage', 'diffusion' and 'translation' in the management of public sector organisations and urban spaces in a context of entrenched conflict and an uncertain path to peace.
\end{abstract}

Key words: Conflict transformation, urban management, public managers, bricolage, diffusion, translation, Northern Ireland 


\section{Introduction}

It is increasingly recognised that societies moving out of conflict often struggle with the spatial and social legacies of violence and segregation (Bollens 2000, Brinkerhoff 2005). Such environments are often unstable. Initiating and sustaining the transition from conflict requires multi-pronged approaches aimed at building a sufficient anticonflict infrastructure to act as a brake on renewed conflict (Brinkerhoff and Brinkerhoff 2002, UnitedNations 2010, Bollens 2012). Security, effective delivery of public goods and services, managing political participation and ensuring accountability are all functions necessary for the effective stabilisation of fragile, conflict affected states and plural societies (Bissessar 2009, Brinkerhoff, Wetterberg et al. 2012). Achieving these functions frequently requires change at institutional, organisational and political levels (Brown 1999, Murphy 2013, O'Connor 2014). The context, content and process of change often constitutes a significant blockage in the stabilisation, normalisation and peace building processes which such states are so greatly reliant on (Goldie and Murphy 2010). Even if these core functions develop successfully, the dual difficulties of economic recovery and the risk of future conflict remain (Collier, Hoeffler et al. 2008, Coakley and Todd 2014). With a few notable exceptions, (Raco and Lin 2012, Fagan and Sircar 2015) to date, little research has looked at the process of engaging in challenging institutional change, with the backdrop of violent conflict, trauma and political as well as organisational, resistance to change (Murphy 2013).

The mechanisms of institutional, legislative and community based conflict reduction and peace building has been the subject of much of the literature around transition and conflict transformation (Bissessar, 2009; Bollens, 2011). Good governance, security sector reform and the development of active citizenship are all seen as significant in establishing peace, pursuing state reconstruction and preventing future conflict (Kasirova 2014). Economic regeneration, political participation, legacy issues and what is euphemistically termed 'living with the past' are also important concerns as processes move forward (Berg and Schaefer 2009, McDowell and Braniff 2014). Contested space (Yiftachel and Yacobi 2003, Morrissey and Gaffikin 2006, Calame and Charlesworth 2009, Bollens 2011) represent a significant and sometimes daily challenge for those charged with managing public places. As institutional agents in 
such an environment, public managers perform a dual role of interpreting policy and implementing it within a contested political space and place. This is a challenging endeavour, often requiring public managers who have a skilled and nuanced understanding of the exogenous political environment and the equally important administrative context of their organisation (Goldie and Murphy 2015). Existing studies have tended to focus on the role of elite level bureaucrats in sustaining conflict-managing mechanisms and decision making processes (O'Connor 2014). Despite invoking the idea of institutional entrepreneurs as agents of change (DiMaggio 1988), the institutional literature has also largely focused on powerful actors and neglected the role of managers in coping with and shaping the dynamics of change (Maguire, Hardy et al. 2004, Lounsbury and Crumley 2007). Thus, the role of managers (as agents of institutional change and implementers of urban policy) and the mechanisms facilitating political progress in public sector post conflict contexts are not well understood (Brinkerhoff 2005; Bollens 2000; O’Connor 2014).

Using witness seminars, a methodology developed to initiate focused discussions about issues such as policy development and implementation at pivotal moments (Allen, Allen et al. 2004, Todd 2010), we trace the outworking of the mechanisms of institutional change through the management of contested policy implementation. We observe the combining and recombining of existing institutional knowledge and tacit political and community experience. The findings suggest that public sector managers are acting as 'imaginative bricoleurs' (Campbell, 2004) within conflict environments, employing diffusion and translation to navigate complex socio-political, legislative and spatial landscapes. The introduction of new elements into the situation through the emerging peace process have allowed managers to expand their repertoire and reach, and in some cases resolve, issues more effectively than political agents at the elite or social agents at a community level. New legislative provision has facilitated this process further.

In the sections that follow we begin by building a theoretical framework to further our understanding of the agents and mechanisms of institutional change and its interaction with complex conflict management dynamics. We then document the background to the case study (Northern Ireland) and the historic role of public sector managers through the Northern Ireland conflict. In doing so we highlight the processes by 
which managers have sought to innovate around difficult and challenging conditions during active conflict, on the hard climb of conflict transformation and the Gordian knot of post conflict environments, 'dealing with the past'. The paper concludes with some reflections on the previously obscured role of public managers in such environments, the usefulness of a mechanism based explanation, and the implications of this for public management and conflict transformation processes in the future.

\section{Theoretical framework: the agents and mechanisms of institutional change}

Public sector managers are faced with considerable demands during periods of violent conflict and in the transition to a less violent, but a still divided extraneous environment. Both stability and change are achieved though dynamic inputs from actors who reproduce the system over time (Weick 1987). Rather than actors following rules, either consciously by imitation or coercion or unconsciously by tacit agreement, as assumed in some forms of institutional theory, (DiMaggio 1988, Jepperson 1991), actors have interests, resources, or positions within the system and have the potential to change the system (Stone 1989, Fligstein 2001) by securing "enough co-operation among disparate community elements to get things done"(Stone, 1989: 227).

In times of change new "cultural frames" or "logics of action" come into existence. Individuals frame lines of action, and mobilize people in the service of these action frames (Fligstein 2001, Snow and Benford 1988, Snow 1992, Jasper 2004, Jasper 2006). Actors interact with knowledge of one another under a set of common understandings about purpose, relationships and the rules that govern legitimate action (McAdam and Scott 2005). Actors develop shared understandings about relationships, the "rules of the game" and institutional norms (Scott 1994) that help to establish the boundaries and the appropriate ways of behaving (Lawerence 1999). Socially constructed expectations and practices become disseminated and reproduced (Scott 1994, Scott 1995). We argue that public sector managers play a unique role in this process.

Specifically, public sector managers are central to the retention of institutional memory, which can be eroded during conflict involving population displacement, spatial division and ongoing violence. Managers embody how the organisations 
reflect, remember and learn from past initiatives (Walsh and Ungson 1991, Casey and Olivera 2003, Akgün, Keskin et al. 2012). Their expertise and 'institutional memory' makes them key agents in conflict transformation (Casey and Olivera 2003, McDowell and Braniff 2014). Not only does their presence represent critical continuity in a fluid and volatile environment but their knowledge, networks and experience are invaluable when facing new, unprecedented challenges. For Aguilar, (2002, 21) 'few lessons are learned when the outcome is successful, given that nobody ever enquires into whether this outcome has really been achieved as a result of a political decision, or whether on the contrary, it has been achieved in spite of that decision.') The challenge then for public sector managers is to draw on the past but also allow this learning to shape present and future decisions. In contested public spaces, this is often both necessary and unappetising. Jervis (1976) notes that it is telling 'we cannot make sense out of our environment without assuming that, in some sense, the future will resemble the past' (Jervis 1979: 217). Understanding how such individuals and teams are able to sustain and indeed progress project and policy implementation in such volatility is a question of interest not only in relation to understanding past conflict, but to seeking to better equip managers in the future.

Campbell (2004) explains the process of institutional change through the mechanisms of bricolage, diffusion, translation (Campbell 2004). Bricolage means making do with whatever resources are at hand (Weick 1993) and the process whereby actors recombine locally available institutional principles and practices in ways that yield change' (Campbell 2004: 65). These elements are often borrowed from other contexts, to create a new configuration of social activity (Weick, 1993). Campbell (2004) identifies two types of bricolage: substantive, involving the recombination of already existing institutional principles and practices to address existing problems (March and Olsen 1989) and symbolic engaging in the recombination of symbolic principles and practices acceptable and legitimate inside a broad social environment. The key elements in bricolage are innovative and creative people - 'the bricoleurs' (Campbell, 2004). Diffusion involves the spread of ideas, structures, and practices, often via networks and translation involves the modification and implementation of ideas to work in specific local contexts (Campbell, 2004). In the context of conflict transformation, we can see that such new elements might be legal frameworks, international learning or wider trans-territorial agreements that impact themselves on 
the conflict through the introduction of new actors, practices, new systems or new resource possibilities. We argue that these mechanisms are central to the process of change in societies emerging from ethno-national conflict and the building of an anticonflict infrastructure.

A focus on mechanism-based explanations (Davis and Marquis 2005, Falleti and Lynch 2009) offers a possible route to a better understanding of how managers have been able to cope with and shape change. Mechanism-based explanations pay attention to the roles of context, processes and causality and are particularly relevant to making sense of complex environments (Campbell 2004, Davis and Marquis 2005, Falleti and Lynch 2009). By providing the 'nuts and bolts' (Elster 1989) and 'cogs and wheel's' (Hernes 1998) of wider analysis, mechanisms provide mid-level theory (Merton 1968, Pawson 2002) that better explains social, political and organizational change, and adds texture and detail to better inform understanding of what are otherwise obscured processes. Mechanisms are not variables or attributes and thus not always directly measurable (Hedström and Swedberg 1998). Mechanisms in both the social and physical sciences may be invisible (Hernes 1998). For example, gravity may be unobservable but it does not prevent us from understanding, appreciating and researching its effects. Research can help produce theories of the mechanisms that explain outcome patterns. To better specify and explain such mechanisms necessitates narrative based studies (Davis 2006) which retain the type of 'thick description' (Geertz 1973) of complex social phenomena, such as public sector organisations in a historical context of entrenched conflict.

\section{Public sector managers in Northern Ireland}

While the Northern Ireland conflict has been the subject of much scholarly activity, the role of Northern Ireland's public sector and the impact of the conflict on the sector are much less well understood. Since the Good Friday/Belfast Agreement in 1998 the Northern Ireland public sector has been dominated by the implementation of institutional reform, the active refinement of consociationalist government and the innovation of ambiguity in the political process (Goldie and Murphy 2010). The public sector has often found itself implementing, managing or at a minimum responding to a range of challenging new socio-political and still contested 
environments and with it an implicit recognition that the public sector had a role to play in facilitating progress in conflict transformation (Bollens 2012, O'Connor 2014).

Post conflict related instability, an engrained geography of division, and the legacy of the past has acted as a significant drain on the public and security sector spending in the post-1998 landscape (Nolan 2014). Public managers are often tasked with responding to or managing difficult environments that emanate from a society that remains deeply segregated - fractious commemorative parades need to be policed; the construction of illegal memorials require a response from local government and the Department of the Environment; murals painted onto the properties managed by the Housing Executive present considerable challenges and the contested renaming of parks or streets after political figures needs to be legally assessed. As one participant noted: 'Never, ever underestimate the power of symbolism. The small stuff is far more important symbolically than the big stuff. Managing in this environment is 'an art, more than a science' (Former Chief Executive, Northern Ireland Local Government $26^{\text {th }}$ June, 2013). In a post-agreement context where patterns of conflict and systems of spatial and political segregation shape the relationships between public bodies and society, but also between and within different public bodies, the challenges for addressing persisting conflict-related dynamics remains not only a priority but a defining aspect of their functionality and operationality.

The local Government sector has often faced the worst of daily conflict and been confronted with the ever present concern of service provision in a divided society context. Whilst incidents of physical intimidation and violence often go unrecorded (Jarman 2005), previous studies have shown that service delivery in local councils (Dickson and Hargie 2006), social work (Pinkerton and Campbell 2002, Campbell and McCrystal 2005) leisure services management (Bairner and Shirlow 2003) and adult education (Nolan 2007) has been hindered by ethno-national conflict and division. Some of the most pervasive challenges for public-sector managers have centred on managing the consequences of the conflict and the challenges of the peace. Phases of peacebuilding are commonly understood as dynamic and often progress and regress simultaneously (Macginty and Darby 2000) and the role of public sector managers is further complicated by the shifting sands of the peace process. In the case study of Northern Ireland, we identify three environments of action that are 
overlapped and entangled. The first phase is characterised by active conflict beginning in early 1970's and ending with the paramilitary ceasefires of 1994. The second is the unsteady peace which followed the ceasefires and persisted through the Agreement of 1998, the devolution of power to the Northern Ireland Assembly and the policing transition process. Third is the present period, the challenge of living with the past in the present. Mechanisms themselves oscillate between the varying conflict environments. It is to these experiences that the paper now turns.

Actors' experiences are analysed through three key lenses. The first bricolage in this context and which relates to organisational decision-making and action, which is deeply embedded in the reality of conflict and violence. The second, diffusion sketches out the process whereby new knowledge and people began to impact on the process, the third translation helps explain how new elements introduced into the process, like legislation and structures enabled managers to operate in different ways.

\section{Methodological approach}

The theoretical background informing this study outlined above seeks to explore a complex process of change and instability within public sector organisations operating in environments of violent conflict. As such, the methodology selected needed to be sufficiently flexible to capture diverse views and the participation of organisationally disparate individuals, to provide space for individual and group recollection and reflection and to explore complex organisational processes and institutional norms (Stone, 1989; Fligstein, 2001; Scott, 1994). Data captured the experiences of public sector managers, who were involved in and responsible for policy implementation in Northern Ireland, and whose lived experiences correspond to the management of on-going conflict-related public policy issues, building peace, managing segregated urban environments and responding to continued societal and political change. Witness seminars, developed as a technique to facilitate the creation of material or insights from recent history, allow for the exploration of carefully delineated research questions through focused discussion and provide the opportunity to better understand policy development and implementation at pivotal moments, making them a considered and methodologically innovative choice (Allen, Allen et al. 2004, Coakley and Todd 2014). 
Two witness seminars took place over a six-month period that was particularly marked by commemorative-related violence and increased pressure to reassess or measure the success of post-conflict transition. They engaged thirty public sector managers who hold or have held policy implementation roles in a range of public sector environments, from the early 1970's to the present day. Roughly one third of participants were recently retired, with two thirds holding senior policy implementation roles at the time of the research. Participation was secured through a process of snowball referral and existing research networks (Saunders and Townsend 2016). Individuals were invited to participate and suggest additional invitees from a range of Northern Ireland public sector domains, including health, housing, local government, policing and justice, higher education, arts administration, and the equality and good relations sectors. In general, this resulted in a group of senior and middle managers most of whom had spent their entire professional lives within the Northern Ireland public management sector, and whose careers spanned periods of conflict and conflict reduction. Seminars were arranged in a neutral venue ${ }^{1}$, with two experienced facilitators who both had previous research experience of organisational change during and after active conflict. Conducted as part of the wider research council funded research project, the seminars in design and implementation adhered to strict ethical guidelines in relation to participant's anonymity, data management and storage, experienced facilitation and significant contact with participants beforehand to ensure that the research questions themselves did not raise or provoke difficulty or distress among the participants. However, it may be useful to note that participants were eager to engage and that the witness seminar format was particularly supportive to the discussion of what were sometimes sensitive and complex issues (Svorenčík and Maas 2015).

The first seminar focused on the reality of managing through both communal violence and an emerging peace process and addressed questions such as: How did the reality of living with conflict impact on how the public sector did its business? How did organisations respond and what kind of support did it give to its staff to make those decisions? How was conflict managed on the ground? What impact have you seen from the peace process and what legacy has been left from 30 years of violence? The

${ }^{1}$ In a place with active association to the conflict, or affiliation to a particular political group. 
second on the management of legacy and commemoration sought to explore issues such as: How has the legacy of the past impacted the NI public sector? How do public sector organisations manage and relate to commemorative violence and conflict? How does commemorating the past impact on the streetscape? As one witness seminar participant put it 'These are real issues that had to be dealt with. It's a very difficult reality for organisations' (Retired senior civil servant in devolved government, 26 ${ }^{\text {th }}$ June, 2013). The seminar process allowed participants to describe the nature of the political environment and how they measured their own contribution, resulting in a rich and novel dataset affording participants the opportunity to discuss issues that had previously been self-censored. One interviewee noted, 'it's complex and sensitive to put material into the public domain: that is at the forefront of our mind' (Senior Policy Manager - NI Arts sector, 26 ${ }^{\text {th }}$ June, 2013). All participants agreed that the role of the public sector managers in dealing with conflict and conflict transformation was 'a story which has not yet been told' (Retired Senior Civil Servant, Housing sector, 26 th June, 2013). Seminars were recorded, transcribed and anonymised. Data was restructured to identify timescales and sectors, including inter sector working and spatial links. Two researchers coded the data in relation to the types of political activity engaged in by the managers and discussed differences in interpretation, which were minimal. Codes included 'engagement with local / regional politicians' 'engagement with press' 'engagement with community groups' 'engagement with former paramilitaries'. Codes were further broken down to identify types of engagement such as 'negotiation around public space' 'off the record briefings' etc. For example, a public manager recalling an off the record engagement with the political representatives of a paramilitary group, at a time when it was officially against policy to speak to the political representatives of paramilitary groups was recorded as 'off the record engagement'. This facilitated a focus on change and organisational mechanisms which have otherwise been previously obscured by the wider political process or community engagement. Researchers were conscious of the political and sensitive nature of the material that was being disclosed by actors when discussing the complexities of managing and responding to, and potentially transforming conflict and division in post-agreement Northern Ireland.

\section{Bricolage 'Whatever you do, hold the ground'}


"Context is everything. You manage in the context you're working in. Your staff are products of the environment you're living in. Your politicians are instruments within the things that are happening outside, you do have to stress the need to adapt to that. You don't have one tactic. You have to go where the fissures are in order to make progress" (Retired Senior Manager, Northern Ireland Local Government, $26^{\text {th }}$ June, 2013).

'Finding the fissures', 'Context is everything' - these were two of the core messages that emerged when participants spoke about the reality of managing public sector environments during active conflict phases; these aspects reinforce the salience of institutional memory, firstly to identify the openings and secondly to respond to environments that may be dynamic but may also be repetitive. When we look at the lived experience of public managers in conflict and transition we see different forms of bricolage. Substantive bricolage seems to be evident in the behaviour of managers who use existing institutional principles and practices to create change. The most important element within this process was the political ability of the managers themselves and the need to structure some support around them that could inform their 'logics of action':

'What you really needed was smart, street wise political managers and a huge amount of training around things to do with service quality, equality and things like that' (Retired Department Head, Housing sector $26^{\text {th }}$ June, 2013)

The requirement for public sector mangers to innovate solutions out of elements that seemed almost impossible to reconcile was felt strongly. One departmental leader talked about the contradictions during 'direct rule' from Westminster, which characterised the NI 'troubles'. 'We were told 'Don't speak to Sinn Fein', so you had to find a way to speak to them, without speaking to them, to get anything done'(Retired Department Head, Northern Ireland devolved government $26^{\text {th }}$ June, 2013). In an environment that offered little in the way of an accepted 'logics of action', there was a need for officials to 'find the cracks and fissures and work them', while operating within 'the space in the middle with implied authorisation from politicians, the contradictions of 'political deniability' and an ability to 'frame the conversation' in a way which moved the agenda towards even a minor point of agreement. This was often a pressing concern with the public memorialisation of past conflict or violence. 
Managers also reflected what happens when violence goes from being a backdrop to being an immediate concern. One respondent recalled the volatile and dangerous time-period which was dominated by republican hunger strikes in the 1980's and the real challenges that existed for both politicians and public managers:

'At the time of the hunger strikes, public policy was being made on the hoof. You almost have to understand the Whitehall view of the world, and the locals view of the world, sometimes they don't meet' ( Retired Department Head, Northern Ireland devolved government $26^{\text {th }}$ June, 2013). During this phase of violent conflict in which the governing state was perceived as both upholder and breaker of the law it was unsurprising that the incompatibility of central governmental agendas and the priorities of contested, segregated and often violent communities created a vacuum that public sector managers were forced to fill.

Deepening the application of 'symbolic bricolage', the conflict experience of public sector managers also demonstrates the need to behave in ways that were outside structures but acceptable within broader social conventions. As agents of change, their behaviour was not overtly transformative, but bore impact nonetheless. As one participant noted:

'I think a good officer works in that grey space in the middle, and they work with implied authorisation from politicians who they constantly touch base with and you know, they trust you to move into the space with the proviso that's been given and them being given deniability' (Retired Chief Executive, Northern Ireland Local Government $26^{\text {th }}$ June, 2013).

The need for managers to innovate under pressure and to draw on their own social, political, geographic and territorial knowledge that was far outside institutional training or 'official' practices. Recalling a very difficult period during the Troubles he went on:

'...the economy was going down the tubes, big time. We had the death of the two corporals in West Belfast and prior to that we had Gibraltar, and Michael Stones attack on the graveyard. Ministers panicked big time. They thought West Belfast was going to go down the tubes and it was out of control.....And as far as Ministers were concerned it was 'do anything, experiment. Whatever you do, hold the ground' (Retired Department Head, Northern Ireland devolved government 26 ${ }^{\text {th }}$ June, 2013) 
Even the language in this quote is that of the battlefield rather than the boardroom: which illustrates the need to use all available resources to impact on and steady the organisational and community environment.

Such dangerous and unstable situations required creativity, innovation and political acuity. They required individuals at all levels to negotiate, often without internal or external support, the attendant organisational and personal risk. Another participant reflected on the pitfalls while being conscious of the longer-term impact:

'Today's creativity is tomorrow's accountability. People are trying to work out all the time what the balance of forces they are actually dealing with and try to find that thing that might actually engage with it in a way that doesn't bring the house down onto your head. But maybe creates another piece of the platform to keep moving. A huge amount of it was intuitive and was an immediate reaction to events which were at times, certainly for the organisations themselves, overwhelming. (Chief Executive, Northern Ireland Local Government 29 ${ }^{\text {th }}$ Oct, 2013)'

The need for political astute managers was never far away, highlighted again by the post agreement atrocity of the August 1998 Omagh bomb in which 31 people were killed. A participant recalled:

"The other snapshot for me was Omagh....Again, it was the system saying, 'go and do something. We don't know what it is but get on the ground'. A task force moved in immediately after the bombing. There was no plan, they were trying to pick a number of people they thought they could trust. Who were streetwise enough to do something" (Retired Department Head, Northern Ireland devolved government $26^{\text {th }}$ June, 2013).

Managing the reality of political of dissonance was also a concern and a challenge. This was particularly in regard to community and territorial demarcation and division. The role (for good or ill) of specific individuals, political dramas (like intraparamilitary feuds) and constant fragile low level agreements are illustrated in an unofficial internal doctrine of 'Don't ask don't tell' (Senior Manager, Housing sector, $29^{\text {th }}$ Oct, 2013) around policy decisions, especially around community interfaces. The need for managers to 'boundary span' between organisations themselves, local and often polarised communities, and ever present paramilitary structures all led to a 
policy implementation environment which was often fraught, always highly political, and consistently unstable and dangerous.

\section{Diffusion of knowledge, networks and new possibilities}

One of the significant opportunities of the emergent peace process was development of new and powerful networks of knowledge transfer between those within Northern Ireland and those outside who had experience of similar contested societies and organisational challenges. The development of these networks was facilitated by the substantive financial investment in community and institutional programs aimed at peace building, infrastructural development and cross border linkages. Since the late 1980's, an estimated four billion dollars in in peace-focused grant aid has been invested in Northern Ireland, the majority of which has been directed towards the region's civil society and local government sectors (Kelly and Braniff 2016). 'Peace monies', as they came to be called, facilitated peacebuilding and conflict management work at a community and institutional level to build capacity, contact and knowledge exchange between people, groups and organisations in Northern Ireland and other areas where similar challenges arose (Braniff and Byrne 2014, Kelly and Braniff 2016).

For example, the significant network building around policing, and particularly community policing capacity in the newly instituted Police Service of Northern Ireland, included an international programme of work and the involvement of senior policing figures from the USA and Canada in 'remaking' an accountable and acceptable police service (McAllister 2004, Ellison and Pino 2012, Morrow, Mc Allister et al. 2013, Murphy 2013). For example, international exchange visits resulted in changed practice regarding inter-communal tensions around parading (Jarman 2005) yet the impact of other interventions, especially at a community level appeared less obvious (Braniff and Byrne 2014).

These innovative networks and the knowledge that went with them also presented new challenges. Many witness seminar contributors commented on the difficult transition from old established ways of working, to new unsteady paths. As one said, 'It's more difficult to do anything now than then" (Senior Manager, Northern Ireland Devolved Government $29^{\text {th }}$ Oct, 2013). The uncertainties of the new terrain with 
competing and contending pressures from internal political wrangling and external political pressures often forced the public sector in challenging directions. One key issue for many of the contributors is working with a society still in conflict while publically espousing a post-conflict label. As one participant observed: 'The post conflict tag which we now have in some ways... actually masks a legacy of issues which are not resolved - which are ever present - there under the surface threatening to bubble up as occasions arise' (Chief Executive, Northern Ireland Local Government $29^{\text {th }}$ Oct, 2013). The description of Northern Ireland as a post-conflict context serves several purposes for the public sector: it helps to disguise the complexities of the sectarian and segregated society that Northern Ireland remains despite formidable investment at tackling these issues; it normalises the complexities of legacy issues such as victimhood and commemoration; it shifts focus from 'dealing' with conflict to transforming society.

\section{Translation: Knowledge, Legislation and Institutions}

The development of the paramilitary ceasefires and peace process culminating in the 1998 Agreement introduced new significant elements into the conflict transformation process. The introduction of these features, such as additional legislation around equality and good relations, reform and redesign of policing, devolution of power to the new NI Assembly all acted as reinforcement scaffolding for the further building of peace - in a similar way to Campbell's original 'reinforced concrete' metaphor (Campbell 2004), the introduction of new elements allowed for public sector mangers to begin to innovate in ways that had not been possible before. For example, in recent work about flags and symbolism, we can see how legislation round equality and good relations impacted on public managers approach to the issue of the flying of the Union (British) flag on Belfast city council buildings (Goldie and Murphy 2015). In other sectors too, structural and explicit diffusion of knowledge impacted how public managers operated. One senior policing participant commented on the usefulness of new structures around policing and security:

"Whilst a lot of the work that took place on the ground grew organically through relationships I also think it's really important to recognise how valuable sometimes an imposed structure was - and I use the example of the day that Sinn Fein took their 
seats on the policing board in 2007" (Retired, Area Commander, Police Service of Northern Ireland, $26^{\text {th }}$ June, 2013)

Sinn Féin, the political wing of the largest paramilitary wing the IRA, had traditionally been opposed to policing. Interpreted as a representative of the British State, the IRA had considered police officer's legitimate targets in its armed campaign (this extended to potential Catholic officers which deterred recruitment and fed into a force that was not representative of Northern Irish society). Post-conflict legislation surrounding reforms to policing provided the structures to engage organisations like Sinn Fein in the policing process signalled a key milestone in the peace process, while also embedding a stronger function for the public sector at navigating complex and contested political issues and spaces. Additional legislative changes, like Section 75 of the NI Act 1998 (the equality and good relations duty) were also mentioned as change drivers which gave mangers new tools and possibilities. For example, the explicit acknowledgement of community cohesion (in an attempt to undermine social and spatial division) as a defined corporate objective forced council officers to innovate and develop new approaches, as well as revisit existing diplomatic skills. The role of 'smart, streetwise' political managers who had an acute tacit understanding of the partisan environment was underlined as key. Fundamentally, the role of 'management as a political process in conflict' (Senior Manager, Northern Ireland Health Sector, 26 th June, 2013) was reinforced. However, the combative nature of these interventions had not disappeared. One witness seminar participant reflected: 'We had a community cohesion unit - we called it our paramilitary wing' (Senior Manager, Housing sector $26^{\text {th }}$ June, 2013).

While this absorption of new elements created opportunities it also required enormous political and organisational skill to navigate what were still contested political processes and spatial environments. As one manager noted: "You need to create multiple conversations at same time, in different places. You need to have your private conversations with your politicians on your own, one to one, or in bilateral that nobody knows about. Where you have agreed the rules of engagement it is 'what we talk of now we never talk of again' and then you have your semi-public space where you can engage bilaterally to explore concepts, then you have your public space which you know, is the line you have to take which is defendable to the media 
who never disappoint - they will always act as lowest common denominator" (Retired Chief Executive, Northern Ireland Local Government $26^{\text {th }}$ June, 2013).

The inherently political nature of management activity and the associated risks - even in times of peace were foremost in the minds of the witness seminar participants:

"You manage the risk of that and sometimes you have to accept that it going to be tipped over and you have to manage that, so as you're not completely vulnerable. There will always be an audit and the people who told you to do it will be gone. You gotta be like an iceberg - 9/10's of you needs to be below the surface" (Retired Chief Executive, Northern Ireland Local Government $26^{\text {th }}$ June, $201329^{\text {th }}$ Oct, 2013).

The public sector can often predict forthcoming debates, but equally public disputes have the potential to draw them into the heat of public policy in this extreme environment. The role of new legislative frameworks to better manage and diffuse tensions around symbolism has been highlighted before, particular in relation to the incendiary Belfast City Council flag dispute of 2013 (Goldie and Murphy 2015). Another participant recalled difficulty over the reworking of a paramilitary mural in Belfast. The original aim of an 'apolitical mural' to replace the original paramilitary depiction was lost amid the realisation that a 'less militant, threatening, aggressive' image was the 'Best you're going to get' (Senior Manager, Northern Ireland Arts Sector $29^{\text {th }}$ Oct, 2013) illustrating the fundamental compromise at heart of depiction. Within the Arts Management sector, the significance of diversity management and the opportunity to make positive interventions was signalled out as foremost in the minds of those engaged. The sector has also had to manage the dilemma of 'dealing with the past' - a real burden in environments where so many have suffered in periods of social dislocation, violence and fear, and museums as a 'living metaphor' of an inability to deal with 'the troubles legacy'(Senior Manager, Northern Ireland Arts Sector29 $9^{\text {th }}$ Oct, 2013).

Reinforcing the intricate and often thorny environment in which public sector managers are working to design and deliver a range of policy initiatives, organisationally and on the ground, the witness seminars established that there are 
pertinent issues to be considered for how governance can be understood in societies moving out of conflict.

\section{Bricolage, diffusion and translation as the obscured mechanisms of public sector conflict management}

This paper has drawn on the lived experiences of public managers from a range of sectors in Northern Ireland to attempt to determine the underlying mechanisms assisting public sector managers to cope with the consequences of both war and peace. Our finding suggest public sector managers as key agents, play are role of 'imaginative bricoleurs' (Campbell 2004) in the resolution of conflict and the development of innovative solutions to intractable community difficulties. The most significant observation in relation to the observable outworking's of these mechanisms is the nature of the interaction between the mechanisms themselves which in itself, reinforces and strengthens the impact. The bricolage of managers, using existing structures and accepted processes in innovative ways helps us to understand some of the difficult and controversial decisions that were made during the period of conflict both within organisations and in relation to communities.

The peace agreements and concurrent processes provided scope for a new set of 'culture frames' or 'logics of action' (Snow and Benford 1988, Snow 1992, Fligstein 2001, Jasper 2004, Jasper 2006) for the public sector organisations and their managers to develop innovative and creative responses to complex and entrenched issues. As agents for change in a society emerging from conflict, the public sector has found itself facing challenges which required organisational, political and spatial knowledge. Through the case study of Northern Ireland, central lessons become clear: firstly, understanding and approaching peacebuilding in divided and contested spaces requires attention to be paid to institutional forces they often steer the unsteady elite and community levels while developing 'cultural frames' for current and future practice; secondly, a better understanding of underlying casual mechanisms represents an opportunity to understand more clearly the role played by public sector managers; thirdly, in explaining how contested issues are confronted, tackled or negotiated, the explanations of agents and mechanisms of change shed light on the often over-looked 
nature of change processes, and why they at times fall short. Finally, returning to Campbell's 'imaginative bricoleurs' the evidence points to a public sector which is more influential and actors who are afforded more agency than previously acknowledged within peace building efforts. The mutual reinforcing nature and the sequencing of mechanisms through the phases of conflict and peace gives us an insight into how such mechanisms operate over time. Thus this paper makes a contribution to the public management literature by opening up the role and substance of public manager's contribution to peacebuilding processes. In an increasingly unstable global environment, such an insight is significant in the development of the types of anti conflict infrastructures we see in the Northern Ireland case. The paper also helps to extend our understanding of how conflict transformation processes develop at different levels and highlights the previously largely unacknowledged role of mid level structures and their agents. In doing so it furthers the existing contribution of O'Connor (2014) and Birkerhoff (2005) to develop further an understanding of the role of the public sector in conflict affected states, and extends this work to the management of urban segregation, struggles over the public memorialisation of conflict and the ongoing challenge of contested spaces. Lastly, the paper attempts to answer recent calls to a return to mechanism based theorising in an attempt to better understanding causation and complex social processes (Campbell 2004, Davis and Marquis 2005, Falleti and Lynch 2009) and adds to recent research on the role of government and policy in societies dealing with and transitioning from conflict (Fagan \& Sircar 2015; Raco \& Lin 2012).

\section{Conclusion}

This paper highlights the crucial role of public sector managers as agents of institutional change in societies emerging from ethno-political and inter-communal conflict. Drawing on Campbell (2004), we explain the process of institutional change in post conflict Northern Ireland through the mechanisms of bricolage, diffusion and translation. We refer to these as 'obscured mechanisms' not only because mechanisms by their nature are hidden, but because the role of public managers in securing and building peace has been known, sometimes acknowledged but rarely understood as a significant aspect of the conflict transformation process. Drawing on data from a witness seminar initiative with public sector managers who were involved 
in and responsible for policy implementation, we find that public managers when faced with difficult, fast moving and often dangerous situations on the ground take decisions to both manage the immediate implications of that context but also develop long term actions at a strategic level. Rather than conforming to institutional rules and expectations, actors have interests, resources, and positions within the system and can bring about change by securing the cooperation of others. Not only does their presence represent critical continuity in a fluid and volatile environment but their knowledge, networks and experience are invaluable when facing new, unprecedented challenges. Crucially, we find public sector managers are central to the retention of institutional memory, which can be eroded during conflict. We argue that in societies with a history of bloodshed and injury, militarisation, securitisation and segregation public sector managers embody how organisations and communities reflect and remember, and play a central role in managing contested spaces.

\section{References}

Aguilar Fernández, P. (2002). Memory and Amnesia: The Role of the Spanish Civil War in the Transition to Democracy, Berghahn Books.

Akgün, A. E., H. Keskin and J. Byrne (2012). "Organizational emotional memory." Management Decision, 50 (1): 95 - 114.

Allen, D. C. E. C. S. P., P. Allen, N. Black, A. Clarke, N. Fulop and S. Anderson (2004). Studying the Organisation and Delivery of Health Services: Research Methods, Taylor \& Francis.

Bairner, A. and P. Shirlow (2003). "When leisure turns to fear: understanding the reproduction of ethno-sectarianism in Belfast. ." Leisure Studies, 22,(3 ): 247276.

Berg, M. and B. Schaefer (2009). Historical Justice in International Perspective: How Societies Are Trying to Right the Wrongs of the Past, Cambridge University Press.

Bissessar, A. M. (2009). "Challenges Facing Senior Public Servants in a Plural Society." Public Personnel Management 38(1): 1-15.

Bollens, S. (2011). City and Soul in Divided Societies, Routledge.

Bollens, S. A. (2000). On Narrow Ground: Urban Policy and Conflict in Jerusalem and Belfast. . Albany, NY, State University of New York Press.

Bollens, S. A. (2012). City and Soul in Divided Societies, Routledge.

Braniff, M. and J. Byrne (2014). " Circle of Friends: unravelling the networks of peacebuilding in Northern Ireland." Peacebuilding 2. 
Brinkerhoff, D. W. (2005). "Rebuilding governance in failed states and postconflict societies: core concepts and cross-cutting themes." Public Administration and Development 25(1): 3-14.

Brinkerhoff, D. W. and J. M. Brinkerhoff (2002). "Governance Reforms and Failed States: Challenges and Implications." International Review of Administrative Sciences 68 511-531.

Brinkerhoff, D. W., A. Wetterberg and S. Dunn (2012). "Service Delivery and Legitimacy in Fragile and Conflict-Affected States." Public Management Review 14(2): 273-293.

Brown, D. R. (1999). "Ethnic politics and public sector management in Trinidad and Guyana." Public Administration and Development 19(4): 367-379.

Calame, J. and E. Charlesworth (2009). Divided Cities; Belfast, Beirut, Jerusalem, Mostar, and Nicosia,. Philadelphia, University of Pennsylvania.

Campbell, J. and P. McCrystal (2005). "Mental health social work and the troubles in Northern Ireland " Journal of Social Work, 5(2): 173-190.

Campbell, J. L. (2004). Institutional Change and Globalization, Princeton University Press.

Casey, A. and F. Olivera (2003). Learning from the past: A review of the Organisational Memory Literature. Organisational Learning and Knowledge. Lancaster University.

Coakley, J. and J. Todd (2014). "Breaking Patterns of Conflict in Northern Ireland: New Perspectives." Irish Political Studies 29(1): 1-14.

Collier, P., A. Hoeffler and M. Söderbom (2008). "Post-Conflict Risks." \ournal of Peace Research 45(4): 461-478.

Davis, G. F. (2006). "Mechanisms and the Theory of Organizations." Journal of Management Inquiry 15(2): 114-118.

Davis, G. F. and C. Marquis (2005). " Prospects for organization theory in the early 21st century: institutional fields and mechanisms." Organization Science 16(4): 332-343.

Dickson, D. and O. Hargie (2006). "Sectarianism in the Northern Ireland workplace." International Journal of Conflict Management, 17(1): 45-65.

DiMaggio, P. (1988). Interest and agency in institutional theory. Institutional patterns and culture. L. Zucker. Cambridge, MA: , Ballinger: pp. 3-32.

DiMaggio, P. J. (1988). Interest and agency in institutional theory. Institutional patterns and organizations. L. Zucker. Cambridge, MA:, Ballinger. : 3-22.

Ellison, G. and N. Pino (2012). Globalization, Police Reform and Development: Doing it the Western Way?, Palgrave Macmillan.

Elster, J. (1989). "Social Norms and Economic Theory." The Journal of Economic Perspectives 3(4): 99-117.

Fagan, A. and I. Sircar (2015). "Europeanisation and multi-level environmental governance in a post-conflict context: the gradual development of environmental impact assessment processes in Bosnia-Herzegovina." Environment and Planning C: Government and Policy 33(5): 919-934.

Falleti, T. G. and J. F. Lynch (2009). "Context and Causal Mechanisms in Political Analysis." Comparative Political Studies 42(9): 1143-1166.

Fligstein, N. (2001). "Social Skill and the Theory of Fields." Sociological Theory 19(2): 105-125.

Geertz, C. (1973). The Interpretation of Cultures: Selected Essays, Basic Books. 
Goldie, R. and J. Murphy (2010). "Embedding the Peace Process: The Role of Leadership, Change and Government in Implmenting Key reforms in Policing and Local Government in Northern Ireland." International journal of peace studies 15(v. 8-9).

Goldie, R. and J. Murphy (2015). "Belfast beyond violence: Flagging up a challenge to local government?" Local Government Studies 41(3): 470-488.

Hedström, P. and R. Swedberg (1998). Social Mechanisms. An Analytical Approach to Social Theory. Cambridge, Cambridge University Press.

Hernes, G. (1998). Real Virtuality. Social Mechanisms. An Analytical Approach to Social Theory. P. Hedström and R. Swedberg. Cambridge, Cambridge

University Press.

Jarman, N. (2005). No Longer a Problem? Sectarian Violence in Northern Ireland. . University of Ulster., Institute for Conflict Research: .

Jasper, J. (2004). "A Strategic Approach to Collective Action." Mobilization 9: 116.

Jasper, J. (2006). Getting Your Way: Strategic Dilemmas in the Real World. Chicago, University of Chicago Press.

Jepperson, R. L. (1991.). Institutions, institutional effects, and institutionalism. The new institutionalism in organizational analysis. W. W. Powell and P. J. DiMaggio. Chicago:, University of Chicago Press: 143-163.

Jervis, R. (1976). Perception and Misperception in International Politics, Princeton University Press.

Kasirova, D. (2014). "Implmentation of post conflict reconstruction and development aid initiatives: Evidence from Afganistan " Џournal of International Development 26: 887-914.

Kelly, G. and M. Braniff (2016). "A dearth of evidence: tackling division and building relationships in Northern Ireland." International Peacekeeping 23(3): 442-467.

Lawerence, T., B. (1999). " Institutional Strategy." \ournal of Management Inquiry 25: 161-188.

Lounsbury, M. and E. T. Crumley (2007). "New Practice Creation: An Institutional Perspective on Innovation." Organization Studies 28(7): 993-1012.

Macginty, R. and J. Darby (2000). The Management of Peace Processes. Basingstoke, Macmillan.

Maguire, S., C. Hardy and T. B. Lawrence (2004). "Institutional Entrepreneurship in Emerging Fields: HIV/AIDS Treatment Advocacy in Canada." The Academy of Management Journal 47(5): 657-679.

March, J. G. and J. P. Olsen (1989). Rediscovering Institutions: The Organizational Basis of Politics, Free Press.

McAdam, D. and R. W. Scott (2005). Organizations and Movements. Social Movements and Organization Theory. G. F. Davis, D. McAdam, R. W. Scott and M. N. Zald. Cambridge, UK, Cambridge University Press.: 4-40.

McAllister, B. (2004). Human Rights and Police reform in Northern Ireland. Us Congressional Commission on Security and Cooperation in Europe.

McDowell, S. and M. Braniff (2014). Commemoration as conflict: space, memory and identity in peace processes, Palgrave Macmillan.

Merton, R. K. (1968). Social Theory and Social Structure, Free Press.

Morrissey, M. and F. Gaffikin (2006). "Planning for Peace in Contested Space. ." International Journal of Urban and Regional Research, 30:: 873-893. . 
Morrow, D., B. Mc Allister, J. Campbell and D. Wilson (2013). MEDIATED DIALOGUES AND SYSTEMIC CHANGE IN NORTHERN IRELAND MEDIATED DIALOGUES AND SYSTEMIC CHANGE IN NORTHERN IRELAND-'POLICING OUR DIVIDED SOCIETY' (PODS) 1996-2003. Belfast.

Murphy, J. (2013). Policing for Peace in Northern Ireland: Change, Conflict and Community Confidence, Palgrave Macmillan.

Nolan, P. (2007). "Difference, diversity and difficulty: problems in adult peace education in Northern Ireland. ." International Journal of Educational Management, 27(3): 282-291.

Nolan, P. (2014). Northern Ireland Peace Monitoring Report. Belfast, Community Relations Council 3.

O'Connor, K. (2014). Public Administration in Contested Societies, Palgrave Macmillan UK.

Pawson, R. (2002). "Evidence-based Policy: The Promise of `Realist Synthesis'." Evaluation 8(3): 340-358.

Pinkerton, J. and J. Campbell (2002). "Social Work and Social Justice in Northern Ireland: Towards a New Occupational Space." British Journal of Social Work, 32(6): 723-737.

Pollitt, C. (2013). Context in Public Policy and Management: The Missing Link? Edward Elgar Publishing.

Raco, M. and W.-I. Lin (2012). "Urban Sustainability, Conflict Management, and the Geographies of Postpoliticism: A Case Study of Taipei." Environment and Planning C: Government and Policy 30(2): 191-208.

Saunders, M. N. K. and K. Townsend (2016). "Reporting and Justifying the Number of Interview Participants in Organization and Workplace Research." British Journal of Management 27(4): 836-852.

Scott, W. R. (1994). Institution and organizations: toward a theoretical synthesis. Institutional environments and organizations: structural complexity and individualism. S. R. W. and J. Meyer. Thousand Oaks, SAGE: 55-80.

Scott, W. R. (1995). Introduction: institutional theory and organizations. The institutional construction of organization. W. R. Scott and S. Christensen. Thousand Oaks, SAGE Publications.: xi-xxiii.

Snow, D. A. and R. Benford, D. (1988). "Ideology, Frame Resonance, and Participant Mobilization." International Social Movement Research 1: 197-217.

Snow, D. A. B., R.D. (1992). Master frames and cycles of protest. Frontiers to social movement theory. A. D. Morris and C. McClung Muller. New Haven, CT:, Yale University Press. : 133-155.

Stone, D. A. (1989). "Causal Stories and the Formation of Policy Agendas." Political Science Quarterly 104(2): 281-300.

Svorenčík, A. and H. Maas (2015). The Making of Experimental Economics: Witness Seminar on the Emergence of a Field, Springer International Publishing.

Todd, J. (2010). Northern Ireland: A Multi-Phased History of Conflict, a MultiLevelled Process of Settlement Pathways from Ethnic Conflict. J. e. Coakley, Routledge.

UnitedNations (2010). Reconstructing Public Administation After Conflict: Challenges, Practices and Lessons Learned, United Nations

Walsh, J. P. and G. R. Ungson (1991). "Organizational memory." Academy of Management Review 16(1): 57-91. 
Weick, K. E. (1987). "Organisational Culture as a Source of High Reliability." Californian Management Review XXIX(2): 112-127.

Weick, K. E. (1993). "The Collapse of Sensemaking in Organizations: The Mann Gulch Disaster." Administrative Science Quarterly 38(4): 628-652.

Yiftachel, O. and H. Yacobi (2003). "Urban Ethnocracy: Ethnicization and the Production of Space in an Israeli 'Mixed City'." Environment and Planning D: Society and Space 21:: 673-693, . 